\title{
PEMETAAN NERACA SUMBERDAYA AIR KABUPATEN SABU RAIJUA, NUSA TENGGARA TIMUR, INDONESIA
}

\author{
R. Dwihatmojo a, D. Maryanto ${ }^{a}$ \\ a Badan Informasi Geospasial, Indonesia
}

\section{Article Info:}

Received: 20 August 2015

in revised form: 10 September 2015

Accepted: 1 October 2015

Available Online: 31 October 2015

\section{Keywords:}

Potential water, balance water resources, Sabu Raijua Regency

\section{Corresponding Author:}

Roswidyatmoko Dwihatmojo Geospatial Information Agency Indonesia

Email:

roswidyatmoko.dwihatmojo@big.go. id

\section{Info Artikel:}

Diterima: 20 Agustus 2015 Hasil Revisi: 10 September 2015 Disetujui: 1 Oktober 2015 Publikasi On-Line: 31 Oktober 2015

\section{Kata Kunci:}

Potensi Air, Neraca Sumberdaya Air Kabupaten Sabu Raijua

Kontak Penulis:

Roswidyatmoko Dwihatmojo Badan Informasi Geospasial, Indonesia

Email:

roswidyatmoko.dwihatmojo@big.go id

\begin{abstract}
The balance of water resources reflects changing water resource potential within a certain time. Sabu Raijua Regency is a regency in East Nusa Tenggara Province that has physical problems in the water supply. This study aims to identify the potential, utilization, and the balance of water resources in Sabu Raijua Regency. The method used is quantitative and spatial analysis to calculate the potential, utilization, and balance water resources. The results showed potential and utilization of water in Sabu Raijua. The balance of water resources showed greater 'aktiva' than 'pasiva', and there is still a balance of 415,453,645.75 $\mathrm{m}^{3} /$ year. This condition also shows that Sabu Raijua Regency has a surplus of water resources within a period of one year. However, in a certain period (July-September) it experiences a deficit of water resources so that it needs good water resource management to anticipate the problem.
\end{abstract}

\begin{abstract}
Abstrak: Neraca sumberdaya air menggambarkan perubahan potensi sumberdaya air dalam kurun waktu tertentu. Kabupaten Sabu Raijua merupakan salah satu Kabupaten di Provinsi Nusa Tenggara Timur yang memiliki permasalahan fisik dalam penyediaan air. Penelitian ini bertujun untuk melihat potensi, pemanfaatan, dan neraca sumberdaya air di Kabupaten Sabu Raijua. Metode yang digunakan adalah analisis kuantitatif dan spasial untuk menghitung potensi, pemanfaatan, dan neraca sumberdaya air. Hasil penelitian menunujukkan besarnya potensi dan pemanfaatan air di Kabupaten Sabu Raijua. Neraca sumberdaya air menunjukkan aktiva lebih besar dibanding pasiva sehingga masih terdapat saldo sebesar 415.453.645,75 $\mathrm{m}^{3}$ /tahun. Kondisi ini juga menunjukkan bahwa Kabupaten Sabu Raijua mengalami surplus sumber daya air dalam kurun waktu satu tahun. Namun pada bulan tertentu (juliseptember) terjadi defisit sumberdaya air sehingga dibutuhkan arahan pengelolaan sumberdaya air untuk mengantisipasi permasalahan tersebut.
\end{abstract}

\section{PENDAHULUAN}

Kabupaten Sabu Raijua merupakan salah satu kabupaten yang berada di Provinsi Nusa Tenggara Timur. Kabupaten Sabu Raijua terdiri dari dua pulau utama yakni Pulau Sabu dan Pulau Raijua. Pulau di Kabupaten Sabu Raijua sebagai pulau terluar sehingga memiliki peranan strategis sebagai wilayah perbatasan negara. Sumberdaya alam merupakan salah satu isu strategis dalam pengelolaan wilayah, perencanaan pembangunan melihat kondisi dan potensi wilayah yang dimiliki. Proses memahami kondisi eksisting dan prediksi mengenai dinamika sumberdaya air untuk berbagai kegiatan sangat dibutuhkan (Jain et.al, 2010). 
Salah satu permasalahan yang dihadapi adalah kemiskinan dan keterbatasan sumberdaya khususnya air, oleh karena itu dipandang perlunya upaya untuk melihat potensi dan pemanfaatan sumberdaya air.

Kabupaten Sabu Raijua sebagai Daerah Otonomi Baru berdasarkan Undang-Undang Nomor 52 Tahun 2008 memandang perlu melakukan penyusunan neraca sumberdaya alam spasial Kabupaten Sabu Raijua demi tercapainya kelestarian fungsi ekosistemnya. Untuk mendukung keberhasilan usaha tersebut perlu diketahui lokasi keterdapatan potensi dan kondisi sumberdaya alam yang ada di suatu wilayah sehingga dapat dibuat perencanaan yang tepat dalam pengembangan wilayah tersebut (Gambar 1).

Salah satu alternatif untuk mendukung pengembangan pemanfaatan potensi sumberdaya alam yang ada di suatu wilayah dapat dilakukan melalui penyusunan neraca sumberdaya alam. Penyusunan neraca sumberdaya alam merupakan modal atau langkah awal untuk pemanfaatan sumberdaya alam dan untuk menghitung ketersediaan sumberdaya serta potensi pendapatan daerah yang dapat dihasilkannya. Selain itu dataset meteorologi sangat dibutuhkan untuk menyusun potesi sumberdaya air di suatu daerah (Remesan dan Holman, 2015). Penyusunan neraca sumberdaya alam ini berkaitan dengan bagaimana pengelolaan sumberdaya alam yang dapat menguntungkan baik secara ekonomi dan lingkungan serta adanya kelangsungan bagi kesejahteraan masyarakat untuk generasi sekarang dan generasi penerusnya.

Gambar 1. Peta Administrasi Kabupaten Sabu Raijua (Badan Informasi Geospasial, 2004)

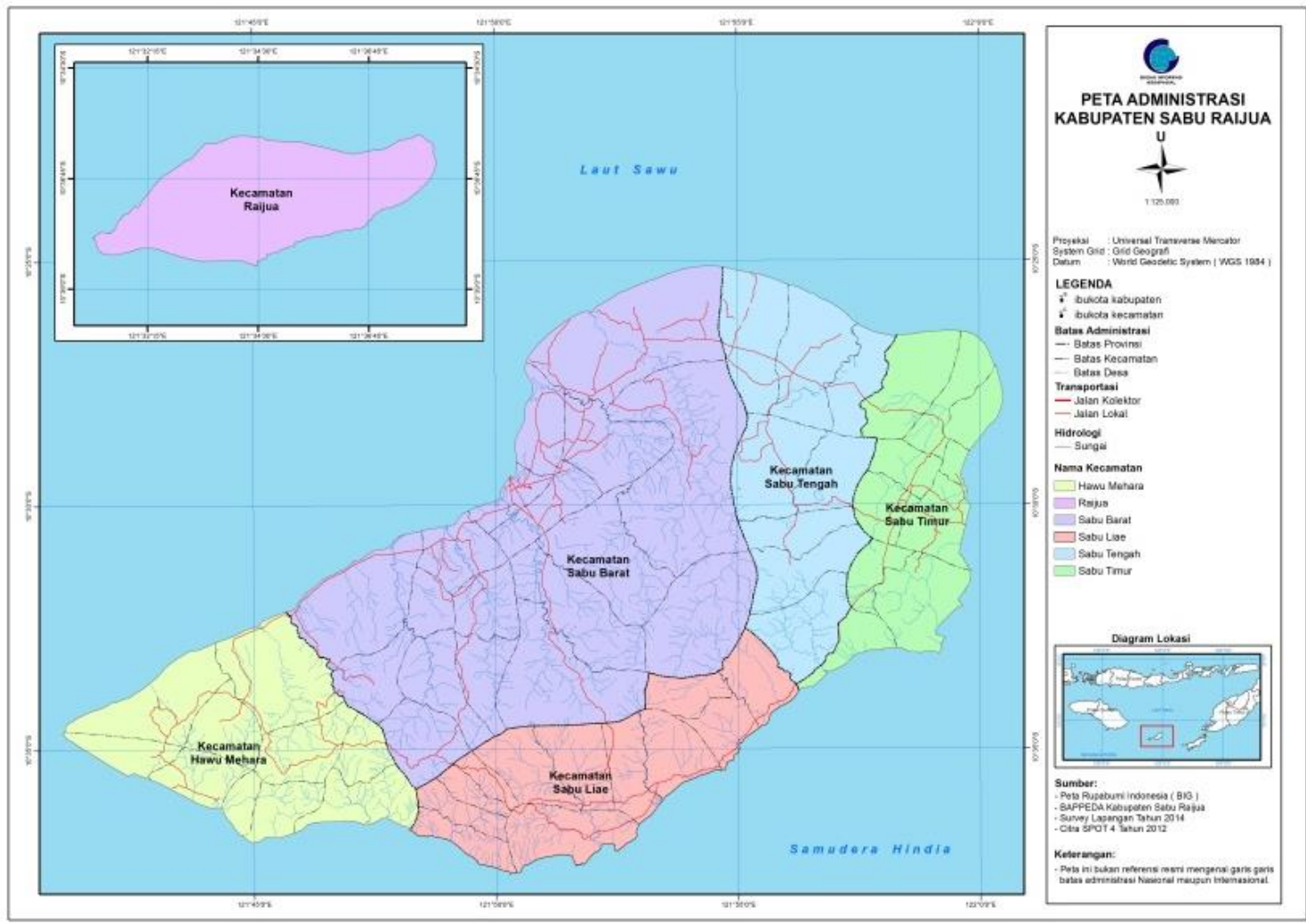

Berdasarkan latar belakang tersebut, penelitian sebagai salah satu upaya untuk mengetahui besaran dan sebaran potensi sumberdaya air daerah untuk menyusun strategi pemanfaatan dan pengelolaan sumberdaya air di daerah. Aspek penggunaan lahan juga diperhatikan sebagai dasar dalam menyusun strategi interaksi sumberdaya air dengan pola pemanfaatanya (Yang, 2015). Penelitian ini bertujuan untuk mengetahui potensi sumberdaya air, pemanfaatan sumberdaya air, dan menghitung neraca sumberdaya air untuk evaluasi sumberdaya air Kabupaten Sabu Raijua.

\section{DATA DAN METODE}

Neraca spasial menekankan penyusunan informasi neraca dengan memanfaatkan informasi keruangan atau geospasial. Neraca sumberdaya air spasial adalah "timbangan", yang disusun untuk mengetahui besarnya cadangan awal sumberdaya air atau potensi air yang dinyatakan dalam aktiva, dan besarnya 
pemanfaatan / penggunaan air yang dinyatakan dalam pasiva serta dinyatakan dalam sistem koordinat tertentu. Perubahan cadangan dapat diketahui melalui besarnya sisa cadangan yang dinyatakan dalam saldo dalam suatu daerah dan dalam suatu kurun waktu karena air bersifat dinamis sehingga analisis multivariat sangat dimungkinkan untuk melihat dan mengukur keberlanjutan manajemen sumberdaya air (Hunter et al., 2015)

Kerangka neraca sumberdaya air dalam bentuk model tabulasi statistik berupa tabel diskontro (sebelah menyebelah) seperti dalam neraca keuangan. Penyusunan neraca sumberdaya lahan sebenarnya adalah memberikan informasi tentang perubahan potensi sumberdaya air dalam suatu kurun waktu yang dinyatakan dalam aktiva dan pasiva.

\subsection{Potensi Sumberdaya Air (Aktiva)}

a) Air Permukaan

Berdasarkan data yang tersedia, perhitungan debit dapat dilakukan antara lain dengan cara berikut ini :

\section{- Analisa regional}

- Estimasi debit pada suatu lokasi berdasarkan atas perbandingan luas DAS dari pos duga air dengan lokasi yang akan dihitung dan dengan atau tidak mempertimbangkan faktor curah hujan.

- Data debit yang tersedia harus memenuhi kriteria panjang data minimal 10 tahun dan telah dilakukan pengujian data.

\section{- Metode hujan - limpasan}

Berhubung data curah hujan umumnya tersedia dengan periode yang lebih panjang dari data debit, maka estimasi debit diperoleh dengan cara perhitungan analisa sintetis berdasarkan data curah hujan yang terjadi. Data curah hujan telah dilakukan pengujian data dan merupakan data curah hujan rata-rata di DAS (diperoleh berdasarkan hasil perhitungan poligon thiesen, isohyet). Dalam metode ini subyektivitas dan asumsi bahwa trend curah hujan dan debit mempunyai trend yang sama, apabila data curah hujan dan debit menunjukan trend yang berbeda maka sebaiknya cara ini tidak dilakukan.

\section{- Distribusi Normal}

Perhitungan debit andalan persatuan waktu (setengah bulanan atau sepuluh harian atau bulanan) dengan menggunakan metoda Distribusi Normal

\begin{tabular}{|c|c|c|}
\hline & Q80 & $=$ Qrata-rata $-0,84 *$ SD \\
\hline Dimana: & $\begin{array}{l}\text { Q80 } \\
\text { Qrata-rata } \\
\text { SD } \\
\text { SD }\end{array}$ & $\begin{array}{l}=\text { debit setengah-bulanan } 80 \% \\
=\text { debit rata-rata untuk setengah-bulanan } \\
=\text { deviasi standar } \\
=((\Sigma(\mathrm{Xi}-\mathrm{Xm}) 2) /(\mathrm{r}-1) 0,5\end{array}$ \\
\hline Dimana : & $\begin{array}{l}X i \\
X m \\
R\end{array}$ & $\begin{array}{l}=\text { nilai data untuk setengah bulanan } \mathrm{i} ; \\
=\text { rata-rata untuk semua nilai } \mathrm{X} ; \\
=\text { jumlah tahun data. }\end{array}$ \\
\hline
\end{tabular}

b) Air bawah tanah

a. Perhitungan cadangan air bawah tanah diperlukan data-data tebal akuifer, sebaran akuifer dan transmisibilitas akuifer baik akuifer tidak tertekan maupun tertekan. Untuk bisa terpenuhinya data ini sangat sulit, maka cadangan airtanah disetarakan dengan imbuhan air tanah yang berasal dari air hujan.

b. Air hujan sebagian menjadi air permukaan dan sebagian meresap kedalam tanah. Perkiraan awal imbuhan dapat di hitung dengan mengambil prosentase tertentu dari curah hujan rata-rata tahunan (Rf) yang meresap ke reservoar air bawah tanah. Ketelitian metode ini tergantung pada angka prosentase imbuhan yang terpilih. Imbuhan pada akuifer dapat dihitung sebagai berikut:

$$
\begin{aligned}
& \mathrm{RC}=\mathrm{RF} \times \mathrm{A} \times \mathrm{RC}(\%) \\
& \mathrm{RC}=\operatorname{imbuhan}\left(\mathrm{m}^{3} / \text { tahun }\right)
\end{aligned}
$$


$\mathrm{RF}=$ Curah hujan rata-rata tahunan di daerah tingkapan dihitung dengan metode Isohyet dan Poligon Thiessen.

A = Luas area/tadah $\left(\mathrm{m}^{2}\right)$ dihitung dengan planimeter, tidak termasuk sawah irigasi.

$\mathrm{RC}=$ Prosentase imbuhan.

Imbuhan tersebut ditambah perhitungan imbuhan dari infiltrasi rata-rata (IR) dari daerah sawah yang terletak pada daerah akuifer. Jika padi hanya ditanam pada saat musim hujan (1 kali panen) diperlukan hitungan imbuhan dengan menggunakan prosentase imbuhan (RC \%).

c. Keseimbangan air di cekungan

Keseimbangan air dapat digunakan untuk menghitung imbuhan dengan;

Formulasi (Walton 1970);

$$
\mathrm{RF}=\mathrm{Ro}+\mathrm{Eta}+\mathrm{Ab}+\mathrm{Qg} \pm \Delta \mathrm{SM} \pm \Delta \mathrm{Sg}
$$

Dimana :

$\mathrm{RF}=$ Curah hujan rata-rata tahunan

Ro = Limpasan ir permukaan, diukur secara langsung dari aliran dasar pada stasiun pengukur sungai.

Eta = Evapotranspirasi nyata.

$\mathrm{Ab}=$ Pengambilan Airtanah

Qg = Airtanah yang mengalir di daerah batas cekungan dengan menggunakan persamaan Darcy.

$\Delta S M=$ Perubahan dalam simpanan kelengasan tanah, dihitung dengan keseimbangan kelengasan tanah.

$\Delta \mathrm{Sg}=$ Perubahan dalam cadangan airtanah

\section{Formulasi Darcy;}

$$
\mathrm{Qg}=\mathrm{T} . \mathrm{I} . \mathrm{L}
$$

\section{Dimana}

Qg = Airtanah yang mengalir di daerah batas cekungan

$\mathrm{T} \quad=$ Keterusan $\left(\mathrm{m}^{2} /\right.$ hari $)$

I = Gradient hidrolika

$\mathrm{L} \quad=$ Lebar akuifer

Dalam metode ini semua komponen dihitung kecuali $\Delta \mathrm{SM}, \Delta \mathrm{SM}$. $\Delta \mathrm{Sg}$ ini akan seimbang sepanjang tahun, artinya akan positif pada musim hujan dan negatif pada musim kemarau. Cara lain salah satunya adalah dengan pendekatan Water balance model Thornwite matter. Dengan pendekatan ini bisa diketahui besarnya runoff bulanan dan besarnya air yang tertahan (detention) dalam bulanan.

Runoff merupakan aliran langsung setelah hujan dan aliran air sungai yang muncul dari mata air. Air detention merupakan air perkulasi yang kemudian mengisi air tanah. Dengan perkiraan besarnya perkulasi ini kita bisa memperkirakan potensi airtanah atau bisa dipakai sebagai pedoman nilai aman besarnya airtanah yang dapat diambil. Data yang diperlukan dalam metode ini adalah data hujan bulanan rata-rata, suhu bulanan rata-rata untuk menghitung penguapan, data penggunaan lahan dan data jenis tanah.

Pendekatan ini dipakai untuk menghitung imbangan air dalam satu-satuan daerah aliran sungai dan kurang disarankan untuk batas wilayah administrasi, seperti formulasi berikut:

$$
P=I+A E T+O F+d S M+d G W S+G W R
$$

Dimana :

$\mathrm{P} \quad \quad=$ Presipitasi

I Intersepsi

AET = Aktual evapotranspirasi 


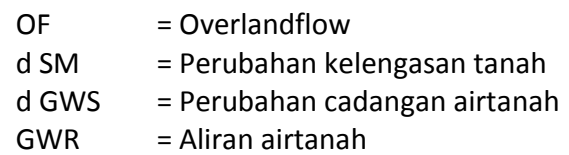

\subsection{Kebutuhan Sumberdaya Air (Pasiva)}

Dalam perhitungan neraca air sebaiknya perhitungan kebutuhan air diperhitungkan dapat memenuhi kebutuhan air multi guna. Kebutuhan air tersebut dapat dikelompokkan menjadi dua bagian yaitu:

- Kebutuhan air non-irigasi meliputi antara lain :

kebutuhan air baku untuk domestik dan non-domestik (pelayanan umum), kebutuhan air industri, kebutuhan air untuk perikanan, kebutuhan air untuk peternakan, dll.

- Kebutuhan air untuk irigasi merupakan kebutuhan air untuk pertanian yang disesuaikan dengan pola tata tanam (luas tanam, jenis tanaman dan tingkat pertumbuhan), kondisi jaringan irigasi.

Dalam perhitungan kebutuhan air pada tiap wilayah sungai ditetapkan sebagai fungsi perkalian antara jumlah pemakai air atau luas daerah irigasi dan satuan kebutuhan air persatuan waktu.

a) Kebutuhan air irigasi

Data air untuk irigasi sudah ada pada masing-masing Dinas Pengelolaan Sumber Daya Air Provinsi atau Kabupaten. Penggunaan air untuk irigasi padi diperhitungkan berdasar luas sawah irigasi teknis, semi teknis dan sederhana yang terdapat dalam DAS yang bersangkutan. Penggunaan air untuk irigasi yang dipergunakan dalam waktu satu tahun sehingga pengaruh lama tanaman dan prosentase (\%) intensitas tanaman harus diperhitungkan.

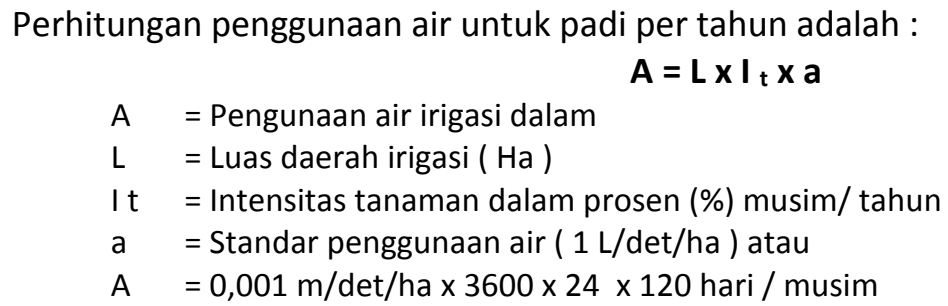

b) Kebutuhan air bersih Rumah Tangga (domestik)

Kebutuhan air bersih rumah tangga adalah air yang diperlukan untuk rumah tangga yang diperoleh secara individu dari sumber air yang dibuat oleh masing masing rumah tangga seperti sumur dangkal, perpipaan atau hidran umum atau dapat diperoleh dari layanan Sistem Penyediaan Air Minum (SPAM) PDAM. Sumber air baku yang dipakai oleh PDAM terdiri dari air tanah, air permukaan atau gabungan dari keduanya. Kebutuhan air bersih rumah tangga, dinyatakan dalam satuan Liter/Orang/Hari (L/O/H), besar kebutuhan tergantung dari kategori kota berdasarkan jumlah penduduk (Tabel 1):

Tabel 1. Kebutuhan Air Bersih Rumah Tangga Menurut Kategori Kota (Dirjen Cipta Karya, 2006)

\begin{tabular}{clll}
\hline No & Kategori Kota & Jumlah Penduduk (Jiwa) & Kebutuhan Air Bersih (L/O/H) \\
\hline $\mathbf{1}$ & Semi Urban & $3.000-20.000$ & $60-90$ \\
$\mathbf{2}$ & Kota Kecil & $20.000-100.000$ & $90-110$ \\
$\mathbf{3}$ & Kota Sedang & $100.000-500.000$ & $100-125$ \\
$\mathbf{4}$ & Kota Besar & $500.000-1.000 .000$ & $120-150$ \\
$\mathbf{5}$ & Metropolitan & $>1.000 .000$ & $150-200$ \\
\hline
\end{tabular}

Dengan asumsi kenaikan kebutuhan air bersih $1 \%$ per tahun, maka kebutuhan air bersih pada tahun 2010 serta prediksinya untuk tahun 2014, 2019 dan 2029 berdasarkan kategori kota, diuraikan pada Tabel 2 berikut: 
Tabel 2. Kebutuhan Air Bersih Rumah Tangga Per Orang Per Hari (Dirjen Cipta Karya, 2006)

\begin{tabular}{lllllc}
\hline \multicolumn{1}{c}{ Kriteria Kota } & Rentang Penduduk (Jiwa) & \multicolumn{3}{c}{ Kebutuhan Air (L/O/H) } \\
\cline { 3 - 6 } & & Tahun 2010 & Tahun 2014 & Tahun 2019 & Tahun 2029 \\
Desa & $3.000--20.000$ & 60 & 62 & 66 & 72 \\
Kota Kecil & $20.000-100.000$ & 90 & 94 & 98 & 108 \\
Kota Sedang & $100.000--500.000$ & 100 & 104 & 109 & 120 \\
Kota Besar & $500.000--1.000 .000$ & 120 & 125 & 131 & 144 \\
Metropolitan & $>1.000 .000$ & 150 & 156 & 164 & 180 \\
\hline
\end{tabular}

Keterangan: Hasil Perhitungan dengan kenaikan kebutuhan air bersih $1 \%$ per tahun

Kebutuhan air bersih rumah tangga diperhitungkan pula untuk kehilangan air yang terdiri dari : (1).Kehilangan dalam proses sebesar $6 \%$; (2).Kehilangan air tidak terhitung yaitu sebesar $25 \%$.

c) Kebutuhan Air Perkotaan (Komersial dan Sosial) - Non Domestik

Kebutuhan air perkotaan, yaitu untuk komersial dan sosial seperti: toko, gudang, bengkel, sekolah, rumah sakit, hotel dan sebagainya diasumsikan antara $15 \%$ sampai dengan $30 \%$ dari total air pemakaian air bersih rumah tangga (Asdak, 2002). Ternyata makin besar dan padat penduduknya cenderung lebih banyak daerah komersial dan sosial, sehingga kebutuhan untuk air komersial dan sosial akan lebih tinggi jika penduduk bertambah.

d) Kebutuhan air industri

Survei kebutuhan air industri diperlukan untuk menentukan rata-rata penggunaan air pada berbagai jenis industri tertentu. Perhitungan kebutuhan air industri dapat diperhitungkan berdasarkan atas:

- jumlah karyawan

- luas air industri

- jenis/tipe industri.

e) Kebutuhan untuk peternakan

Perhitungan kebutuhan air rata-rata untuk peternakan tergantung pada jumlah dan jenis ternak (Tabel 3). Kebutuhan air rata-rata untuk ternak ditentukan dengan mengacu pada hasil penelitian dari FIDP (Ditjen. Pengairan, 1992) yang di muat dalam Technical Report National Water Resources Policy. Secara umum kebutuhan air untuk ternak dapat diestimasikan dengan cara mengalikan jumlah ternak dengan tingkat kebutuhan air berdasarkan persamaan berikut ini:

$$
Q_{E}=\left(q_{(1)} \times P_{(1)}+q_{(2)} \times P_{(2)}+q_{(3)} \times P_{(3)}\right)
$$

$\begin{array}{lll}\text { Keterangan : } & \\ \mathrm{QE} & = & \text { kebutuhan air untuk ternak, (It/hari). } \\ \mathrm{q}(1) & = & \text { kebutuhan air untuk sapi, kerbau, dan kuda, (It/ekor/hari). } \\ \mathrm{q}(2) \quad= & \text { kebutuhan air untuk kambing, dan domba, (It/ekor/hari). } \\ \mathrm{q}(3)= & \text { kebutuhan air untuk unggas, (It/ekor/hari). } \\ \mathrm{P}(1)= & = & \text { jumlah sapi, kerbau, dan kuda, (ekor). } \\ \mathrm{P}(2) & = & \text { jumlah kambing, dan domba, (ekor). } \\ \mathrm{P}(3) \quad= & \text { jumlah unggas, (ekor). }\end{array}$

Tabel 3. Kebutuhan Air untuk Ternak (Dirjen Cipta Karya, 2006)

\begin{tabular}{lc}
\hline \multicolumn{1}{c}{ Jenis Ternak } & Kebutuhan air (It/ekor/hari) \\
\hline Sapi/kerbau/kuda & 40 \\
Kambing/domba & 5 \\
Babi & 6 \\
\hline Unggas & 0,6 \\
\hline
\end{tabular}


f) Kebutuhan untuk perikanan

Kebutuhan air untuk perikanan diperkirakan berdasarkan luas kolam, tipe kolam serta kedalaman air yang diperlukan. Kebutuhan ini meliputi kebutuhan untuk mengisi kolam pada saat awal tanam dan penggantian air. Penggantian air bertujuan untuk memperbaiki kondisi kualitas air dalam kolam. Kebutuhan air untuk perikanan untuk selanjutnya dapat di hitung dengan menggunakan rumus sebagai berikut:

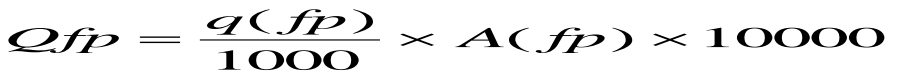

Keterangan :

Qfp = Kebutuhan air untuk perikanan, $\left(\mathrm{m}^{3} / \mathrm{hari}\right)$

$q(f p)=$ Kebutuhan air untuk pembilasan, (It/hari/ha),

$A(f p)=$ Luas kolam ikan, (ha).

g) Kebutuhan untuk penggelontoran atau pemeliharaan sungai.

Menurut Peraturan Pemerintah Republik Indonesia Nomor 38 Tahun 2011 tentang Sungai, aliran pemeliharaan sungai adalah aliran air minimum yang harus tersedia di sungai untuk menjaga kehidupan ekosistem sungai. Perlindungan aliran pemeliharaan sungai dilakukan dengan mengendalikan ketersediaan debit andalan 95\%, yaitu aliran air ( $\mathrm{m} 3 /$ detik) yang selalu tersedia dalam $95 \%$ waktu pengamatan, atau hanya paling banyak $5 \%$ kemungkinannya aliran tersebut tidak tercapai. Dalam hal debit andalan $95 \%$ tidak tercapai, pengelola sumber daya air harus mengendalikan pemakaian air di hulu.

Dengan demikian besarnya kebutuhan air untuk pemeliharaan sungai dihitung berdasarkan debit andalan Q95\% dari data ketersediaan air yang ada. Direktorat Teknik Penyehatan, Ditjen. Cipta Karya, (1993) menetapkan Unit kebutuhan air sebesar: 10,5 m3/kapita/bulan (atau $350 \mathrm{l} / \mathrm{kapita} / \mathrm{hari}$ ). Angka ini akan menurun sampai $300 \mathrm{l} / \mathrm{kapita} /$ hari pada tahun 2015 selaras dengan pembangunan sistem-sistem pembuangan air (sewerage systems) dan makin banyaknya penduduk yang memanfaatkan sistem tersebut. Diagram alir penelitian dapat dilihat pada Gambar $\mathbf{2}$ di bawah ini.

Gambar 2. Diagram Alir Penelitian (Analisis, 2015)

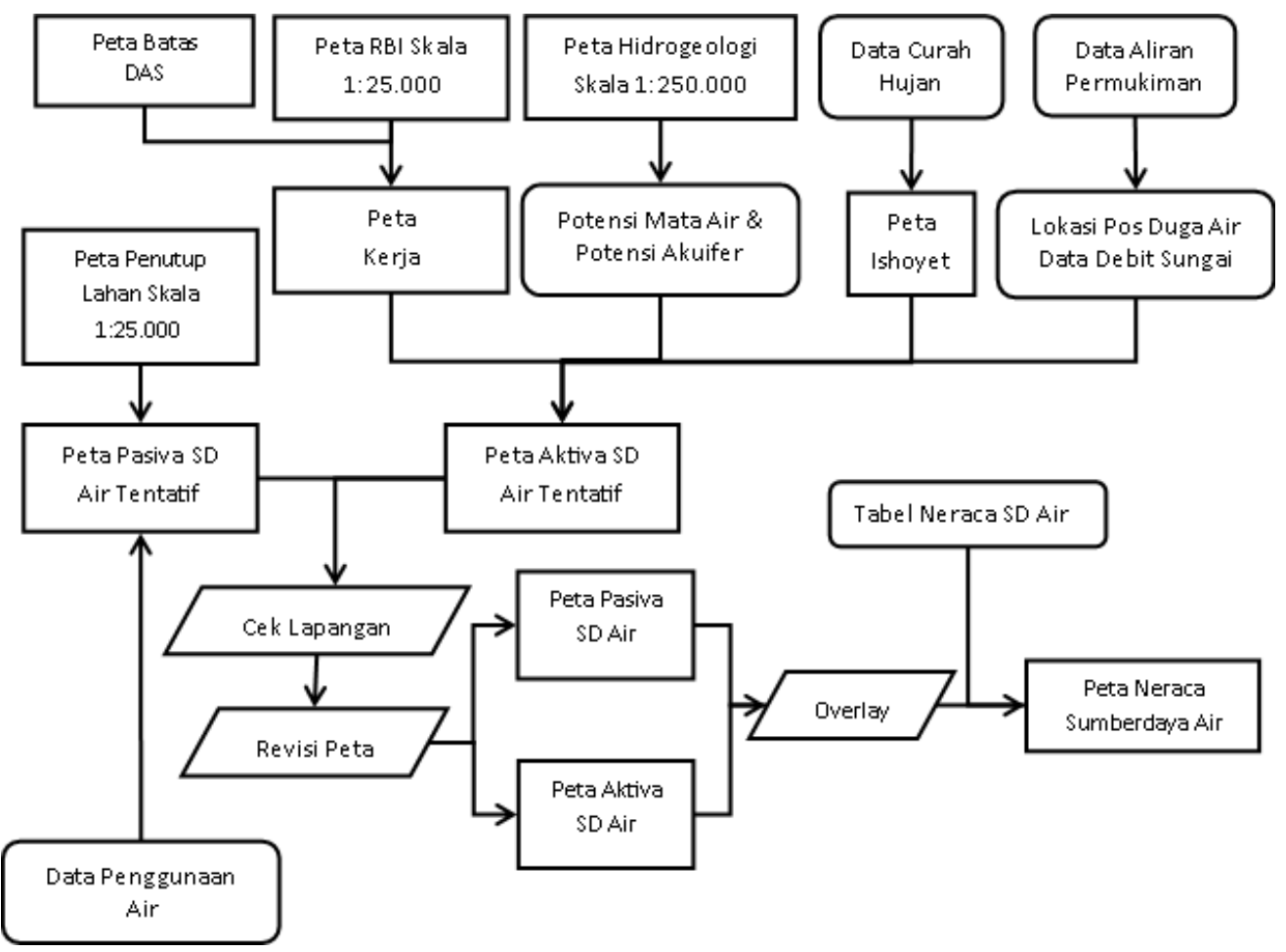




\section{HASIL DAN PEMBAHASAN}

\subsection{Analisis Potensi Sumberdaya Air (Aktiva) di Kabupaten Sabu Raijua}

a) Air Hujan

Hasil perhitungan dengan menggunakan metode Thiesen terhadap data curah hujan tersebut, menunjukkan bahwa potensi tebal curah hujan di Kabupaten Sabu Raijua adalah sebesar 1097,2 mm/tahun atau 504.633.554,76 $\mathrm{m}^{3} /$ tahun. Berdasarkan data tersebut dapat diketahui pula bahwa, curah hujan yang terjadi di Kabupaten Sabu Raijua bagian barat (termasuk P. Raijua) lebih tinggi dibandingkan di sebelah timur. Curah hujan dapat diklasifikasikan menjadi klas rendah (< $1500 \mathrm{~mm} /$ tahun), sedang (1500-2500 $\mathrm{mm} /$ tahun) dan tinggi (2500-5000 mm/tahun).

Berdasarkan seluruh hasil perekaman curah hujan dari 4 stasiun yang ada, menunjukkan bahwa curah hujan rata-rata yang terjadi diseluruh Kabupaten Sabu Raijua termasuk dalam kelas Rendah. Kondisi tersebut tentu akan mempengaruhi potensi sumber daya air baik permukaan, maupun bawah permukaan di wilayah Kabupaten Sabu Raijua, karena air hujan merupakan sumber utama dari kedua jenis potensi air tersebut.

\section{b) Air Permukaan}

Ketersediaan air permukaan di Kabupten Sabu Raijua diperoleh dari perhitungan data hujan setelah dikurangi dengan evapotranspirasi dan pengisian/peresapan air tanah. Pada periode satu tahun, seluruh kecamatan di Sabu Raijua umumnya kemungkinan masih terdapat air permukaan terjadi pada bulan Januari-Juni dan Oktober- Desember, artinya bahwa pada bulan bulan tersebut curah hujan yang terjadi dapat menutupi untuk kebutuhan evapotranspirasi dan resapan. Pada bulan-bulan Juli- September nilai potensi air permukaan nol (atau negatif) menunjukkan bahwa pada bulan tersebut hujan yang terjadi tidak cukup untuk memenuhi kebutuhan evapotranspirasi dan resapan ke dalam tanah.

Potensi air permukaan paling banyak terdapat di Kecamatan Sabu Barat, yaitu kurang lebih 146.538.495,49 $\mathrm{m}^{3} /$ tahun. Disamping karena curah hujannya relatif lebih tinggi di daerah ini, luas wilayahnya juga relatif besar dan mempunyai formasi geologi yang koefisien/prosentase imbuhannya cukup kecil seperti misalnya formasi Bobonaro. Namun demikian fluktuasi potensi air permukaan tersebut cukup tajam, karena pada saat kemarau terjadi defisit air.

Kecamatan yang mempunyai potensi air permukaan terkecil terdapat di Kecamatan Sabu Timur dengan potensi sebesar kurang lebih $26.383 .608,01 \mathrm{~m}^{3} /$ tahun. Empat kecamatan lainnya mempunyai potensi air permukaan berkisar antara lebih dari 36. $\mathrm{m}^{3} /$ tahun hingga kurang dari $70.000 .000 \mathrm{~m}^{3} /$ tahun. Pola ketersediaan potensi air permukaan mengikuti pola curah hujan, yaitu berbentuk huruf $\mathrm{V}$, karena air permukaan bersumber terutama dari air hujan.

\section{c) Mata Air}

Rata-rata debit total seluruh mata air di Kabupaten Sabu Raijua berkisar 92,27 I/det, dengan total potensi airnya adalah sebesar $2.909 .827 \mathrm{~m}^{3} /$ tahun. Secara temporal, debit mata air polanya mengikuti pola tebal curah hujan, yaitu naik pda musim hujan dan menurun pada musim kemarau. Dari sisi spasial (adminsitrasi), pemunculan air tanah (mata air) paling banyak berada di wilayah Kecamatan Hawu Mehara. Mata air yang debitnya relaif besar antara lain Mata Air Lok Eimada dan Limagu di Sabu Timur, Mata Air Depe Ae di Hawu Mehara dan Mata Air Menia di Raijua.

\section{d) Air Tanah}

Formasi batuan paling luas adalah Kompleks Bobonaro, yakni kurang lebih $217.578 .530,46 \mathrm{~m}^{2}$, namun nilai prosentase imbuhan hanya sebesar $5 \%$, sedangkan formasi paling sempit arealnya adalah Formasi Ofu, yaitu sekitar $9.868 .125,46 \%$ dengan prosentase imbuhan hanya 5\%. Selain dipengaruhi oleh nilai prosentase imbuhan, besarnya resapan air hujan juga dipengaruhi oleh besarnya curah hujan itu sendiri. Hasil perhitungan besarnya air yang meresap ke dalam tanah menunjukkan bahwa Formasi Batu Gamping Koral yaitu mencapai kurang lebih 55.499.245,38 $\mathrm{m}^{3} / \mathrm{thn}$, yang tersebar di bagian utara dan barat Pulau Sabu, dan disekeliling Pulau Raijua. Adapun yang terkecil terdapat pada Formasi Ofu yaitu sebesar $491.008,92 \mathrm{~m}^{3} / \mathrm{thn}$, yang secara spasial berada di bagian selatan Pulau Sabu. Adapun total besarnya volume resapan seluruh kabupaten adalah sebesar $80.756 .150,17 \mathrm{~m}^{3} / \mathrm{thn}$. Volume resapan inilah yang berpotensi menjadi air tanah yang diperhitungkan dalam neraca sumber daya air. 
Kecamatan Sabu Barat mempunyai potensi air tanah paling banyak yaitu $29.292 .781,88 \mathrm{~m}^{3} /$ tahun, sedangkan paling kecil potensinya yaitu Kecamatan Sabu Liae sebesar $2.896 .244,84 \mathrm{~m}^{3} /$ tahun. Secara temporal pola ketersediaan potensi air tanah mengikuti pola curah hujan, yaitu berbentu huruf $\mathrm{V}$. Hal ini disebabkan karena sumber air tanah berasal dari air hujan. Dari uraian tiap sumber daya air, ketersediaan sumber daya air di Kabupaten Sabu Raijua dapat dikompilasi menjadi sebuah tabel aktiva. Seperti pada Tabel 4 merupakan jenis sumber daya air dalam satuan $\mathrm{m}^{3} /$ tahun untuk masing masing kecamatan. Potensi sumber daya air baik permukaan maupun bawah permukaan paling tinggi adalah Kecamatan Sabu Barat yakni sebesar $176.215 .489,53 \mathrm{~m}^{3} /$ tahun, sedangkan potensi yang paling kecil adalah Sabu Timur yaitu sebesar 37.850.996,87 $\mathrm{m}^{3}$ /tahun. Namun demikian Kecamatan Sabu Timur mempunyai potensi mata air yang paling tinggi yaitu sekitar 559.716,48 m3/tahun. Gambar 3 di bawah menunjukkan peta potensi air Kabupaten Sabu Raijua.

Tabel 4. Aktiva Sumber Daya Air Kabupaten Sabu Raijua $\left(m^{3} / t h n\right)$

\begin{tabular}{lrrrrrr}
\hline Sumberdaya Air & \multicolumn{1}{c}{ Sabu Barat } & Sabu Tengah & Sabu Timur & \multicolumn{1}{c}{ Sabu Liae } & Hawu Mehara & \multicolumn{1}{c}{ Raijua } \\
\hline Air Hujan & $203.453 .857,74$ & $60.342 .145,54$ & $42.816 .462,93$ & $54.244 .145,85$ & $89.464 .217,55$ & $54.312 .725,14$ \\
Air Permukaan & $146.538 .495,49$ & $39.133 .687,46$ & $26.383 .608,01$ & $41.169 .556,47$ & $69.265 .349,42$ & $36.518 .308,98$ \\
Mata Air & $384.212,16$ & $3.162,24$ & $559.716,48$ & $56.920,32$ & $388.006,85$ & $278.909,57$ \\
\hline Air Tanah & $29.292 .781,88$ & $13.571 .455,76$ & $10.907 .672,38$ & $2.896 .244,84$ & $12.987 .546,94$ & $11.100 .448,37$ \\
\hline Aktiva & $176.215 .489,53$ & $52.708 .305,47$ & $37.850 .996,87$ & $44.122 .721,63$ & $82.640 .903,21$ & $47.897 .666,91$ \\
\hline
\end{tabular}

Gambar 3. Peta Potensi Air Kabupaten Sabu Raijua (Analisis, 2014)

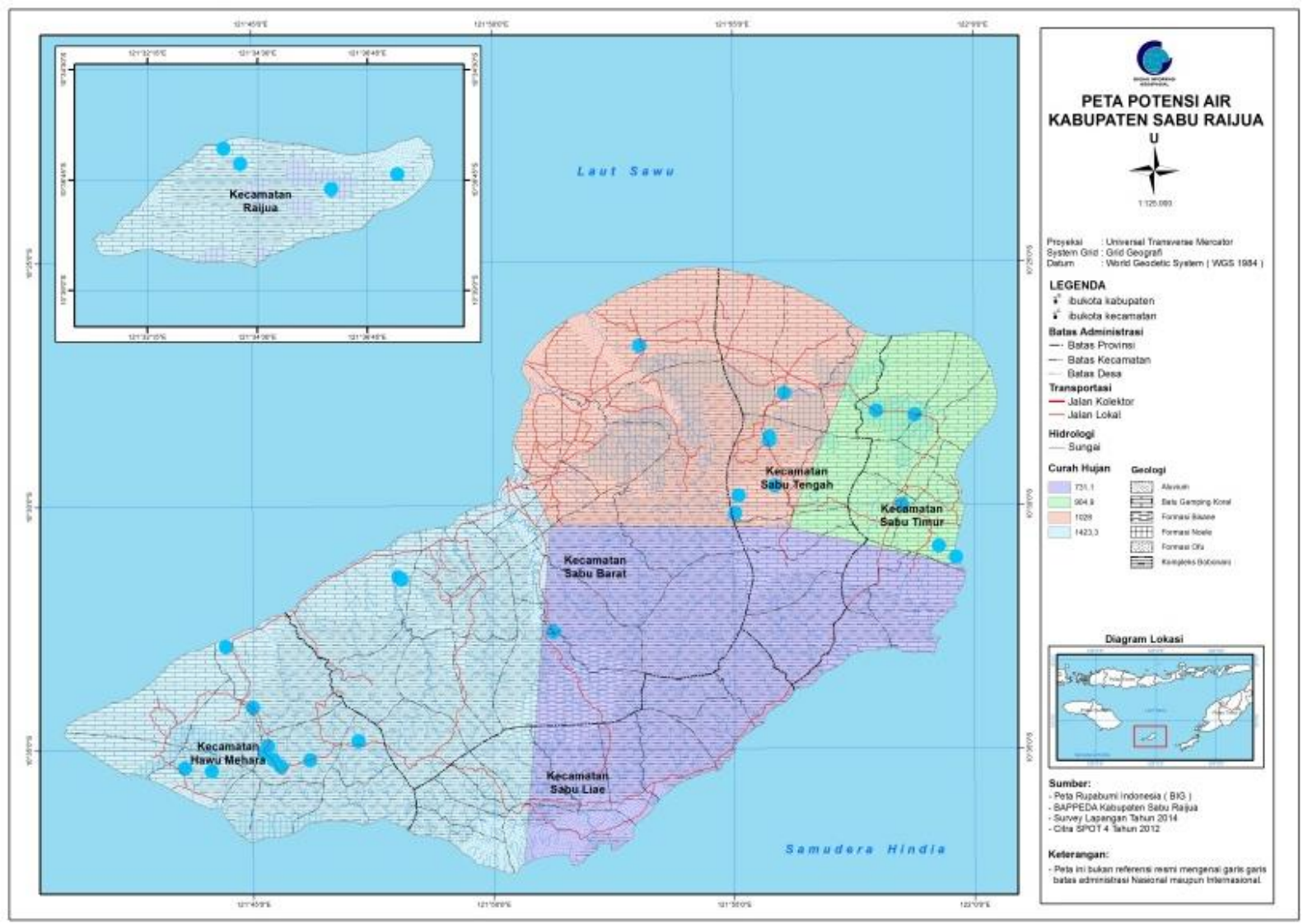




\subsection{Analisis Kebutuhan Sumberdaya Air (Pasiva) di Kabupaten Sabu Raijua}

\section{a) Air Domestik}

Penggunanan air untuk keperluan domestik paling banyak di Kecamatan Sabu Barat sebesar 893.257,20 $\mathrm{m}^{3}$ /tahun yang disebabkan jumlah penduduk tinggi sehingga kebutuhan perkapita juga lebih tinggi. Urutan jumlah penggunanan selanjutnya dari besar ke yang lebih kecil yaitu Hawu Mehara $\left(346.326,60 \mathrm{~m}^{3} /\right.$ tahun); Sabu Liae (199.421,40 m³/tahun); Raijua (172.637,70 m³/thun); Sabu Timur (166.878,00 $\mathrm{m}^{3} /$ tahun); dan paling sedikit adalah Sabu Tengah $\left(162.782,70 \mathrm{~m}^{3} /\right.$ tahun). Kebutuhan domestik yang terutama adalah mandi, cuci dan kakus. Berdasarkan hasil perhitungan di atas, total penggunaan air untuk domestik di Kabupaten Sabu Raijua adalah 1.941.304,60 $\mathrm{m}^{3} /$ tahun.

\section{b) Air Non Domestik}

Penggunaan untuk non domestik sebenarnya mencakup banyak kegiatan, namun keterbatasan data maka hanya diperhitungkan kegiatan pendidikan dan kesehatan. Penggunaan untuk non domestik diperhitungkan jumlah murid sedangkan di bidang kesehatan diperhitungkan jumlah puskesmas. Total penggunaan air untuk kebutuhan non domestik sebesar $114.015 \mathrm{~m}^{3} /$ tahun.

c) Air untuk Peternakan

Hasil perhitungan kebutuhan air untuk peternakan diketahui bahwa Kecamatan Sabu Barat merupakan wilayah paling banyak mempunyai ternak, baik sapi, kerbau maupun kuda hingga ternak unggas sebesar 169.953.855 $\mathrm{m}^{3} /$ tahun. Kecamatan Sabu Timur meskipun variasi hewan ternaknya lebih banyak dibanding Raijua namun jumlahnya sedikit maka kebutuhan airnya paling kecil yaitu sebesar $28.290,20 \mathrm{~m}^{3} / \mathrm{thn}$.

\section{d) Air untuk Pertanian}

Data luas sawah irigasi diperoleh dari data dalam angka dan hasil interpretasi citra. Total kebutuhan air untuk pertanian yaitu sebesar 22.560.768.00 $\mathrm{m}^{3} /$ tahun. Penggunaan air tertinggi di Kecamatan Sabu Barat yaitu sebesar $9.476 .352,00 \mathrm{~m}^{3} /$ tahun karena luas sawah paling besar. Disusul kemudian Kecamatan Sabu Tengah dengan penggunaan air sebesar $8.356 .608,00 \mathrm{~m}^{3} /$ tahun, dan yang paling sedikit adalah Kecamatan Raijua dan Hawu Mehara karena tidak terdapat sawah irigasi.

e) Air untuk Industri

Data jumlah karyawan industri untuk menghitung penggunaan air untuk industri diperoleh dari BPS (Kecamatan Dalam Angka), sedangkan standar penggunaan air untuk industri dapat diperkirakan dengan menggunakan besaran kebutuhan rata-rata yaitu 500 liter/hari/karyawan (PU, 2005). Jumlah total pemakaian air untuk industri di Kabupaten Sabu Raijua sebesar $961.593,00 \mathrm{~m}^{3} /$ tahun. Air tersebut paling banyak digunakan di Kecamatan Sabu Barat yaitu sebesar 913.047,50 $\mathrm{m}^{3} /$ tahun, disusul kemudian Sabu Tengah (20.440,00 $\mathrm{m}^{3} /$ tahun), Raijua (10.950,00 $\mathrm{m}^{3} /$ tahun), Sabu Timur $\left(10.767,50 \mathrm{~m}^{3} /\right.$ tahun) dan Sabu Liae $\left(6.387,50 \mathrm{~m}^{3} /\right.$ tahun $)$.

Tabel 5. Pasiva Sumber Daya Air Kabupaten Sabu Raijua ( $m^{3} /$ tahun)

\begin{tabular}{lcccccc}
\hline Penggunaan & Sabu Barat & Sabu Tengah & Sabu Timur & Sabu Liae & Hawu Mehara & Raijua \\
\hline Domestik & $893.257,20$ & $162.782,70$ & $166.878,00$ & $199.421,40$ & $346.326,60$ & $172.637,70$ \\
\hline Non Domestik & $35.014,45$ & $13.661,95$ & $16.019,85$ & $19.359,60$ & $19.713,65$ & $10.245,55$ \\
\hline Industri & $913.047,50$ & $20.440,00$ & $10.767,50$ & $6.387,50$ & 0 & $10.950,00$ \\
\hline Peternakan & $169.953,86$ & $47.657,25$ & $28.290,20$ & $65.951,27$ & $47.176,40$ & $45.729,76$ \\
\hline Pertanian & $9.476 .352,00$ & $8.356 .608,00$ & $2.923 .776,00$ & $1.804 .032,00$ & 0 & 0 \\
\hline Jumlah & $11.487 .625,01$ & $8.601 .149,90$ & $3.145 .731,55$ & $2.095 .151,77$ & $413.216,65$ & $239.563,01$ \\
\hline
\end{tabular}

Berdasarkan hasil perhitungan yang disajikan pada Tabel 5 dapat diketahui bahwa penggunaan terbesar sumber daya air berada di wilayah Kecamatan Sabu Barat yakni sebesar 11.487.625,01 $\mathrm{m}^{3} /$ tahun, kemudian berurutan hingga ke yang paling sedikit yaitu Kecamatan Sabu Tengah $\left(8.601 .149,90 \mathrm{~m}^{3} /\right.$ tahun), Sabu Timur (3.145.731,55 m³/tahun), Sabu Liae (2.095.151,77 $\mathrm{m}^{3} /$ tahun), Hawu Mehara $(413.216,65$ $\mathrm{m}^{3} /$ tahun) dan paling kecil Raijua $\left(239,563.01 \mathrm{~m}^{3} /\right.$ tahun). Bidang pertanian secara umum merupakan penggunaan air terbesar dibanding bidang lainnya, di bawahnya kemudian bidang domestik, peternakan, industri dan non domestik (Gambar 4). 
Gambar 4. Peta Pemanfaatan Air (Analisis, 2014)

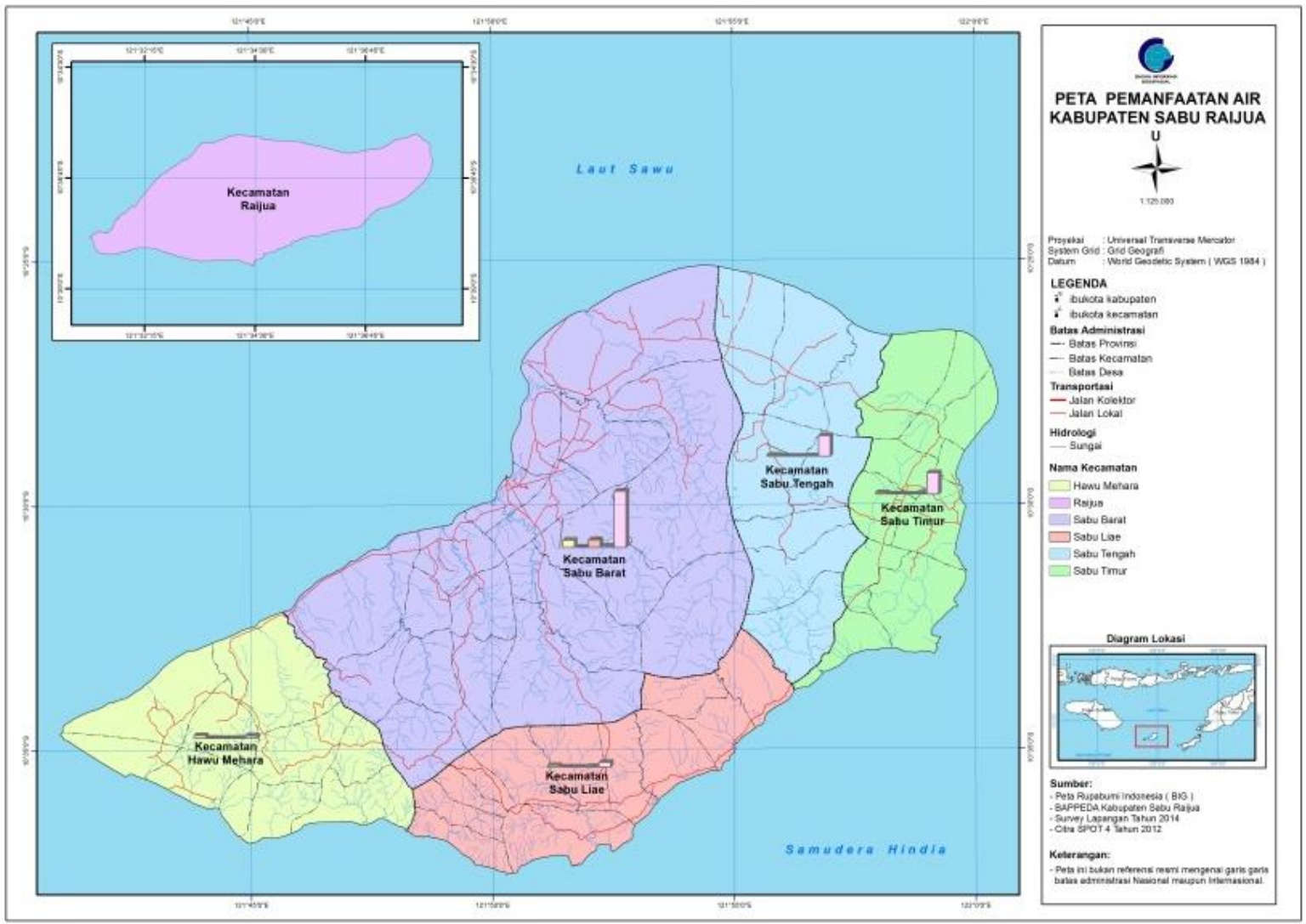

\subsection{Neraca Sumberdaya Air di Kabupaten Sabu Raijua}

Neraca sumber daya air merupakan imbangan antara ketersediaan dan penggunaan sumber daya air. Hasil perhitungan neraca sumber daya air Kabupaten Sabu Raijua disajikan dalam bentuk tabel diskontro (sebelah menyebelah) seperti yang disajikan Tabel 6 di bawah.

Tabel 6. Neraca Sumber Daya Air Kabupaten Sabu Raijua (Analisis, 2014)

Kecamatan : Hawu Mehara

\begin{tabular}{|c|c|c|c|}
\hline Sumber Daya Air & Potensi ( $\left.\mathrm{m}^{3} / \mathrm{th}\right)$ & Penggunaan & Volume ( $\mathrm{m}^{3} /$ tahun) \\
\hline Air Hujan & $89.464 .217,55$ & Domestik & $346.326,60$ \\
\hline Air Permukaan & $69.265 .349,42$ & Non Domestik & $19.713,65$ \\
\hline Mata Air & $388.006,85$ & Industri & - \\
\hline Air Tanah & $12.987 .546,94$ & Peternakan & $47.176,40$ \\
\hline Jumlah A. Permukaan + A. Tanah & $82.640 .903,21$ & Jumlah & $413.216,65$ \\
\hline \multicolumn{4}{|l|}{ Kecamatan : Raijua } \\
\hline Sumber Daya Air & Potensi ( $\left.\mathrm{m}^{3} / \mathrm{th}\right)$ & Penggunaan & Volume ( $\mathrm{m}^{3} /$ tahun) \\
\hline Air Hujan & $54.312 .725,14$ & Domestik & $172.637,70$ \\
\hline Air Permukaan & $36.518 .308,98$ & Non Domestik & $10.245,55$ \\
\hline Mata Air & $278.909,57$ & Industri & $10.950,00$ \\
\hline Air Tanah & $11.100 .448,37$ & Peternakan & $45.729,76$ \\
\hline Jumlah A. Permukaan + A. Tanah & $47.897 .666,91$ & Jumlah & $239.563,01$ \\
\hline
\end{tabular}




\begin{tabular}{|c|c|c|c|}
\hline \multicolumn{4}{|l|}{ Kecamatan : Sabu Barat } \\
\hline Sumber Daya Air & Potensi ( $\left.\mathrm{m}^{3} / \mathrm{th}\right)$ & Penggunaan & Volume ( $\mathrm{m}^{3} /$ tahun) \\
\hline Air Hujan & $203.453 .857,74$ & Domestik & $893.257,20$ \\
\hline Air Permukaan & $146.538 .495,49$ & Non Domestik & $35.014,45$ \\
\hline Mata Air & $384.212,16$ & Industri & $913.047,50$ \\
\hline \multirow[t]{2}{*}{ Air Tanah } & $29.292 .781,88$ & Peternakan & $169.953,86$ \\
\hline & & Pertanian & $9.476 .352,00$ \\
\hline Jumlah A. Permukaan + A. Tanah & $176.215 .489,53$ & Jumlah & $11.487 .625,01$ \\
\hline \multicolumn{4}{|l|}{ Kecamatan : Sabu Liae } \\
\hline Sumber Daya Air & Potensi ( $\left.\mathrm{m}^{3} / \mathrm{th}\right)$ & Penggunaan & Volume ( $\mathrm{m}^{3} /$ tahun) \\
\hline Air Hujan & $54.244 .145,85$ & Domestik & $199.421,40$ \\
\hline Air Permukaan & $41.169 .556,47$ & Non Domestik & $19.359,60$ \\
\hline Mata Air & $56.920,32$ & Industri & $6.387,50$ \\
\hline \multirow[t]{2}{*}{ Air Tanah } & $2.896 .244,84$ & Peternakan & $65.951,27$ \\
\hline & & Pertanian & $1.804 .032,00$ \\
\hline Jumlah A. Permukaan + A. Tanah & $44.122 .721,63$ & Jumlah & 2.095.151.77 \\
\hline \multicolumn{4}{|l|}{ Kecamatan : Sabu Tengah } \\
\hline Sumber Daya Air & Potensi ( $\left.\mathrm{m}^{3} / \mathrm{th}\right)$ & Penggunaan & Volume ( $\mathrm{m}^{3} /$ tahun) \\
\hline Air Hujan & $60.342 .145,54$ & Domestik & $162.782,70$ \\
\hline Air Permukaan & $39.133 .687,46$ & Non Domestik & $13.661,95$ \\
\hline Mata Air & $3.162,24$ & Industri & $20.440,00$ \\
\hline \multirow[t]{2}{*}{ Air Tanah } & $13.571 .455,76$ & Peternakan & $47.657,25$ \\
\hline & & Pertanian & $8,356,608,00$ \\
\hline Jumlah A. Permukaan + A. Tanah & $52.708 .305,47$ & Jumlah & $8,601,149.90$ \\
\hline \multicolumn{4}{|l|}{ Kecamatan : Sabu Timur } \\
\hline Sumber Daya Air & Potensi (m³/th) & Penggunaan & Volume ( $\mathrm{m}^{3} /$ tahun) \\
\hline Air Hujan & $42.816 .462,93$ & Domestik & $166.878,00$ \\
\hline Air Permukaan & $26.383 .608,01$ & Non Domestik & $16.019,85$ \\
\hline Mata Air & $559.716,48$ & Industri & $10.767,50$ \\
\hline \multirow[t]{2}{*}{ Air Tanah } & $10.907 .672,38$ & Peternakan & $28.290,20$ \\
\hline & & Pertanian & $2.923 .776,00$ \\
\hline Jumlah A. Permukaan + A. Tanah & $37.850 .996,87$ & Jumlah & $3.145 .731,55$ \\
\hline Total Aktiva & $441.436 .083,62$ & Total Pasiva & $25.982 .437,87$ \\
\hline
\end{tabular}

Nilai aktiva dihitung dari jumlah air permukaan dan air tanahnya saja, karena air hujan merupakan sumber dari kedua jenis air tersebut. Berdasarkan hasil perhitungan tersebut, dapat diketahui bahwa aktiva lebih besar dibanding pasiva sehingga masih terdapat saldo sebesar $415.453 .645,75 \mathrm{~m}^{3} /$ tahun. Kondisi ini juga menunjukkan bahwa Kabupaten Sabu Raijua mengalami surplus sumber daya air dalam kurun waktu satu tahun. Demikian pula bila dilihat setiap wilayah kecamatan kondisi aktiva masih lebih besar dari pasiva sehingga Kabupaten Sabu Raijua masih mempunyai daya dukung untuk menyangga kehidupannya (Gambar 5). 
Gambar 5. Peta Neraca Air Kabupaten Sabu Raijua (Analisis, 2014)

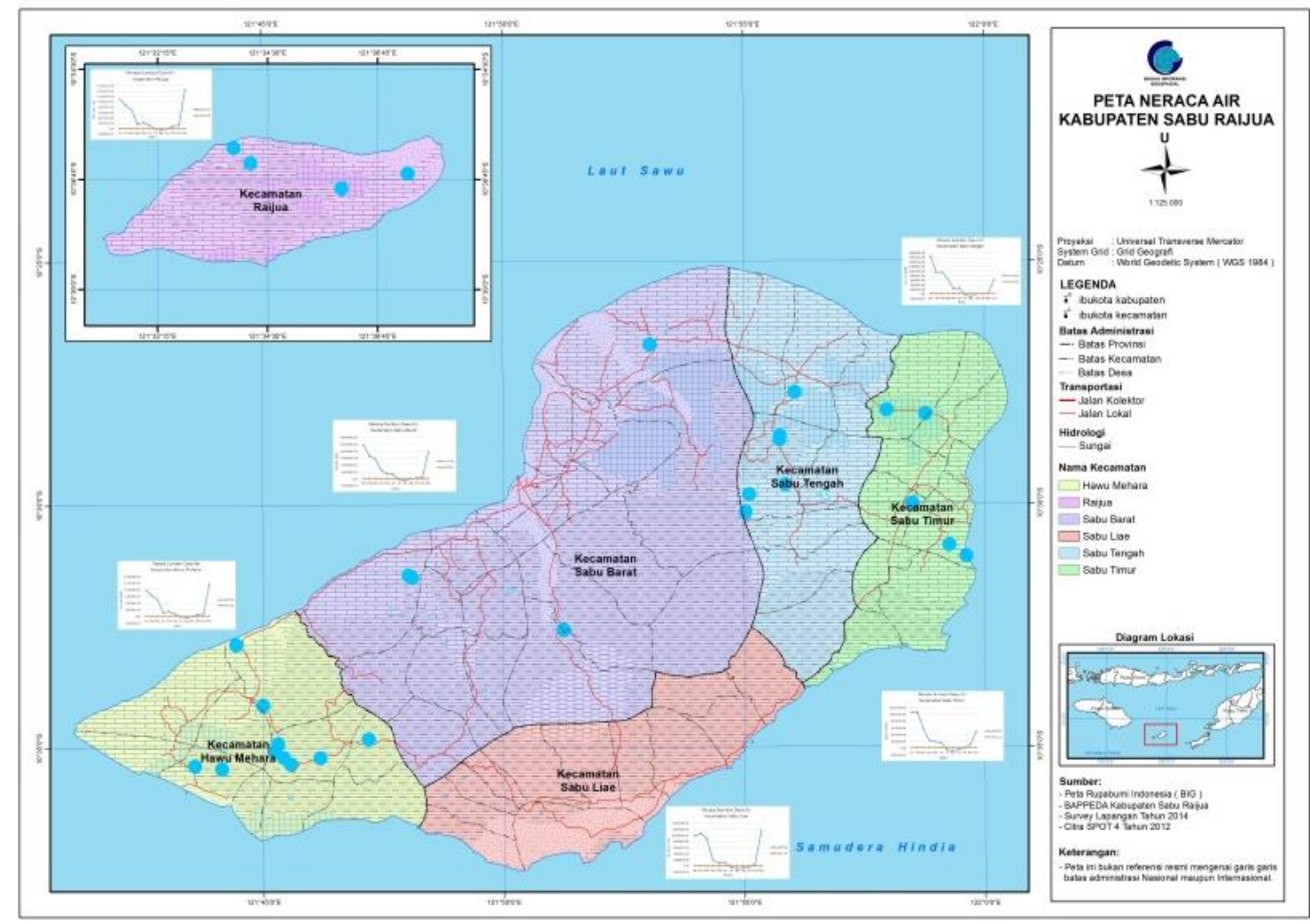

Hal yang perlu untuk dicermati lebih lanjut secara temporal pada tiap kecamatan selain terjadi surplus tetapi juga terjadi defisit. Sebagai indikator awal hasil perhitungan bulanan terhadap besarnya hujan bila dibandingkan dengan besarnya evapotranspirasi dan resapan, menunjukkan bahwa pada bulan Juli, Agustus, dan September mengalami defisit. Artinya air hujan yang jatuh pada bulan tersebut tidak dapat memenuhi kebutuhan untuk evapotranspirasi dan resapan. Jadi secara umum dari perhitungan data aktiva, telah terjadi defisit. Hasil perhitungan neraca air spasial (aktiva, pasiva, dan saldo) menunjukkan bahwa setiap kecamatan mengalami defisit pada bulan Juli, Agustus dan September. Kecamatan-kecamatan yang defisitnya bertambah panjang yaitu Sabu Liae (Oktober), Sabu Timur (Oktober) dan Sabu Tengah (Oktober dan November).

\section{KESIMPULAN}

Curah hujan di seluruh kawasan Kabupaten Sabu Raijua termasuk dalam kelas yang rendah yang mempengaruhi kondisi sumberdaya air di kabupaten tersebut. Hasil penelitian juga menunujukkan besarnya potensi dan pemanfaatan air di Kabupaten Sabu Raijua. Neraca sumberdaya air menunjukkan aktiva lebih besar dibanding pasiva sehingga masih terdapat saldo sebesar $415.453 .645,75 \mathrm{~m}^{3} /$ tahun . Kondisi ini juga menunjukkan bahwa Kabupaten Sabu Raijua mengalami surplus sumber daya air dalam kurun waktu satu tahun. Penggunaan sumber daya air untuk bebagai keperluan adalah berkisar 25,98 $\times 10^{6}$ $\mathrm{m}^{3} /$ tahun, dengan bidang pertanian mempunyai proporsi terbesar yaitu berkisar $22,6 \times 10^{6} \mathrm{~m}^{3} /$ tahun. Bila ditinjau secara tahunan, sumber daya air di Kabupaten Sabu Raijua masih mengalami surplus, namun secara lebih detil, bila dilihat secara bulanan, seluruh kecamatan mengalami defisit pada bulan Juli hingga September.

\section{DAFTAR PUSTAKA}

Asdak, C. (2002). Hidrologi dan Pengelolaan Daerah Aliran Sungai. Yogyakarta: Gadjah Mada University Press.

Bakosurtanal et.al. (2004). Petunjuk Teknis Neraca Sumberdaya Alam Spasial Nasional.

Bakosurtanal. (2001). Neraca Sumberdaya Air Spasial Nasional.

BPS Kabupaten Kupang. (2013). Hawu Mehara Dalam Angka 2013. BPS Kabupaten Kupang. 
(2013). Raijua Dalam Angka 2013. BPS Kabupaten Kupang.

(2013). Sabu Barat Dalam Angka 2013. BPS Kabupaten Kupang.

(2013). Sabu Liae Dalam Angka 2013. BPS Kabupaten Kupang.

(2013). Sabu Raijua Dalam Angka 2013. BPS Kabupaten Kupang.

(2013). Sabu Tengah Dalam Angka 2013. BPS Kabupaten Kupang.

(2013). Sabu Timur Dalam Angka 2013. BPS Kabupaten Kupang.

Br, S. H. (1993). Analisis Hidrologi. Jakarta: PT. Gramedia

Departement Pekerjaan Umum. (2006). Standar Kebutuhan Air Rumah Tangga: Ditjen Cipta Karya

Hunter, et al. (2015). A Dynamic, Multivariate Sustainability Measure for Robust Analysis of Water Management Under Climate and Demand Uncertainty in an Arid Environment. Water, 7(11): 59285958.

Jain et al., (2010). Simulation of Runoff and Sediment Yield for A Himalayan Watershed Using SWAT Model. Journal Water Resources, 2: 267-281.

Remesan, R., \& Holman, I. P. (2015). Effect of Baseline Meteorological Data Selection on Hydrological Modelling of Climate Change Scenarios. Journal of Hydrology, 528, 631-642.

Sekretariat Negara. (2011). Peraturan Pemerintah Republik Indonesia Nomor 38 Tahun 2011 tentang Sungai

Yang, et al. (2015). Simulation of Groundwater-Surface Water Interactions under Different Landuse Scenarios in the Bulang Catchment, Northwest China. Water. 7(11): 5959-5985 